\title{
FAKTOR - FAKTOR YANG MEMPENGARUH AUDIT REPORT LAG PADA PERUSAHAAN 86 INDUSTRI PLASTIK DAN KEMASAN YANG TERDAFTAR DI BEI PERIODE 2013 - 2018
}

\author{
Endang Susilowati; Yuli Chomsatu S²; Suhendro3 \\ Fakultas Ekonomi Universitas Islam Batik Surakarta ${ }^{1,2,3}$; \\ susywiyana@gmail.com'; chom_satoe@yahoo.com² ${ }^{2}$ dro_s@yahoo.com³
}

\begin{abstract}
ABSTRAK
Tujuan dari penelitian ini adalah untuk menguji pengaruh ukuran KAP, rasio keuangan (debt equity ratio, current ratio), opini audit dan ukuran perusahaan terhadap audit report lag. Debt equity ratio tidak berpengaruh terhadap audit report lag. Perusahaan yang memiliki debt-equity ratio yang tinggi ataupun rendah tidak akan mempengaruhi audit report lag sebab setiap perusahaan bertujuan agar kreditor mengetahui kinerja dan kemampuan perusahaan dalam membayar pinjamannya kepada kreditor tersebut. Current ratio berpengaruh terhadap audit report lag. Likuiditas dalam hal ini current ratio mengacu pada ketersediaan sumber daya perusahaan untuk memenuhi kewjiban jangka pendek yang jatuh tempo secara tepat waktu. Ukuran KAP berpengaruh terhadap audit report lag. Perusahaan industri plastik dan kemasan big four dapat dikatakan bahwa KAP non Four mempunyai tenaga spesialis yang profesional yang mampu melakukan audit secara efisien sehingga mampu menyelesaikan laporan audit dengan tepat waktu sesuai peraturan yang berlaku. Opini audit tidak berpengaruh terhadap audit report lag. Ini dikarenakan auditor yang memiliki pengalaman yang cukup lama tidak menjadi kendala dalam mencari bukti - bukti yang diperlukan dalam proses audit, jadi auditor tidak memerlukan waktu yang lama dalam melakukan proses audit, dari temuan - temuan audit yang ada auditor akan mengeluarkan opini audit sesuai dengan bukti temuan tersebut, sehingga laporan audit akan disajikan secara tepat waktu. Ukuran perusahaan tidak berpengaruh terhadap audit report lag. Apabila total aset perusahaan industri plastik dan kemasan yang terdaftar di BEI periode 2013 - 2018 mengalami peningkatan maupun penurunan, maka audit report lag tidak akan mengalami perubahan.
\end{abstract}

Kata kunci: ukuran kantor akuntan publik, rasio keuangan, opini audit, ukuran perusahaan dan audit report lag.

Diterima: 14 September 202O; Direvisi: 21 September 202O; Diterbitkan: 1 Oktober 2020

\section{PENDAHULUAN}

Pentingnya audit report lag suatu laporan keuangan menuntut auditor agar menyelesaikan pekerjaan lapangannya secara tepat waktu. Disisi lain, pengauditan membutuhkan waktu yang cukup dalam mengidentifikasi masalahmasalah yang terjadi dalam perusahaan serta membutuhkan suatu ketelitian dalam menemukan bukti-bukti audit. Untuk menjawab masalah tersebut maka Otoritas Jasa Keuangan (OJK) mengeluarkan aturan tentang publikasi laporan keuangan kepada perusahaan go publik. Perusahaan harus berkala menyampaikan laporan keuangan yang telah diaudit paling lambat 90 hari sejak 
tanggal tutup tahun buku kepada OJK. Apabila peraturan ini dilanggar oleh perusahaan, maka OJK akan memberikan sangsi kepada perusahaan yang bersangkutan.

Keterlambatan

dalam mempublikasikan laporan keuangan dapat menjadikan indikasi bahwa terdapat masalah dalam laporan keuangan emiten sehingga memerlukan waktu yang lebih lama untuk menerbitkan laporan keuangan tersebut pada bursa maupun media cetak lainnya (Masodah dan Mustikaningrum, 2009). Semakin lama waktu publikasi laporan keuangan tertunda, maka semakin banyak kemungkinan berkembangnya rumor - rumor negatif mengenai perusahaan dan hal ini dapat mempengaruhi keputusan yang akan diambil. Dyer dan McHugh (1975) menyimpulkan bahwa ketepatan waktu pelaporan keuangan merupakan elemen pokok bagi catatan laporan keuangan yang memadai

Para pemakai informasi akuntansi tidak hanya perlu memiliki informasi keuangan yang relevan dengan prediksi dan pembuatan keputusan, tetapi informasi juga harus bersifat baru. Ketepatan waktu mengimplikasikan bahwa laporan keuangan seharusnya disajikan pada suatu interval waktu untuk menjelaskan perubahan dalam perusahaan yang mungkin mempengaruhi pemakai informasi dalam membuat prediski dan keputusan.

Audit report lag merupakan rentang waktu dalam menyelesaikan pekerjaan audit hingga tanggal diterbitkannya laporan audit. Diukur berdasarkan lamanya hari yang dibutuhkan untuk memperoleh laporan auditor independen atas audit laporan keuangan tahunan perusahaan, sejak tanggal tutup buku perusahaan yaitu per 31 Desember sampai tanggal yang tertera pada laporan auditor independen.

Terdapat banyak fakor yang mempengaruhi audit report lag. Tingkat solvabilitas, likuiditas dan ukuran perusahaan diperkirakan dapat mempengaruhi audit report lag laporan keuangan. Dengan analisia solvabilitas dapat mengukur kemampuan perusahaan menutupi seluruh kewajiban kewajibannya.

Menurut Carslaw dan Kaplan (1991) proporsi relatif dari utang terhadap total aset mengindikasikan kondisi keuangan perusahaan. Proporsi yang besar dari hutang terhadap total aktiva akan meningkatkan kecenderungan kerugian dan dapat meningkatkan kehati - hatian dan kecermatan yang lebih dalam pengauditan dari auditor terhadap laporan keuangan yang diaudit.

Firnanti (2016) mengatakan bahwa factor-faktor yang mempengaruhi audit report lag yaitu ukuran perusahaan, solvabilitas, reputasi auditor, kinerja perusahaan, umur perusahaan dan likuiditas menunjukan bahwa solvabilitas memiliki pengaruh positif terhadap audit report lag, sedangkan reputasi auditor dan kinerja perusahaan meiliki pengaruh negatif terhadap audit report lag. Dengan demikian investor dan perusahaan dapat memperhitungkan faktor tersebut dalam pembuatan keputusan yang berkaitan dengan audit report lag. Perusahaan juga dapat meningkatkan kinerja sehingga dapat meningkatkan ketepatan waktu penyajian laporan keuangan. 
Iskandar dan Trisnawati (2010) menyebutkan factor-faktor yang mempengaruhi audit report lag yaitu total aset, klasifikasi industri, laba atau rugi tahun berjalan, opini audit, ukuran kantor akuntan, dan debt proportion menunjukan bahwa klasifikasi industri laba atau rugi tahun berjalan dan besarnya KAP berpengaruh terhadap audit report lag. Sedangkan total aset, opini audit dan debt proportion tidak pengaruh terhadap audit report lag.

\section{LANDASAN TEORI}

\section{Teori Keagenan}

Teori keagenan menurut Jensen and Meckling (1976) adalah "teori yang menjelaskan hubungan antara pihak agen (manajemen) dengan prinsipal (pemegang saham)". Dalam hal ini pihak prinsipal sebagai pemilik akan memberikan informasi kepada pihak agen sebagai manajer untuk melakukan pengolahan informasi. Hasil pengolahan informasi dapat digunakan dalam pengambilan keputusan bagi pihak prinsipal. Dalam hubungan prinsipal dan agen tidak selalu terjadi kesesuaian informasi diantara kedua pihak tersebut. Ketidaksesuaian informasi ini disebut asymmetric information antara pihak agen dengan principal.

\section{Audit Report Lag}

Audit report lag dapat didefinisikan sebagai rentang waktu dalam menyelesaikan pekerjaan audit hingga tanggal diterbitkannya laporan audit. Diukur berdasarkan lamanya hari yang dibutuhkan untuk memperoleh laporan auditor independen atas audit laporan keuangan tahunan perusahaan, sejak tanggal tutup buku perusahaan yaitu per 31
Desember sampai tanggal tertera pada laporan auditor independen (Juanita \& Satwiko, 2012).

\section{Ukuran Kantor Akuntan Publik}

Perusahaan akan mencari KAP yang kredibilitasnya tinggi untuk meningkatkan kredibilitas laporan keuangan di mata pemakai laporan keuangan itu. KAP yang lebih besar (Bigfour) dianggap sebagai penyedia jasa audit yang lebih mampu mempertahankan independensi dari pada KAP yang lebih kecil karena mereka biasanya menyediakan berbagai layanan untuk klien dalam jumlah besar, sehingga mengurangi ketergantungan mereka pada klien tertentu. Selain itu, KAP yang lebih besar umumnya dianggap sebagai penyedia kualitas audit yang tinggi dan menikmati reputasi tinggi dalam lingkungan bisnis dan karena itu, akan berusaha untuk mempertahankan independensi mereka untuk menjaga image mereka (DeAngelo, 1981 ; Dopuch, 1984 dalam Nasser et al.

\section{Debt Equity Ratio}

Rasio hutang modal menggambarkan samapi sejauh mana modal pemilik dapat menutupi hutang hutang kepada pihak luar dan merupakan rasio yang mengukur hingga sejauh mana perusahaan dibiayai dari hutang. Rasio ini disebut juga rasio leverage. Rasio leverage merupakan rasio untuk mengukur seberaoa bagus struktur permodalan perusahaan. Struktur permodalan merupakan pendanaan permanen yang terdiri dari hutang jangka panjang, saham preferen dan modal pemegang saham (Wahyono, 2002).

Struktur modal merupakan pembelanjaan permanen dimana mencerminkan pengimbangan antar 
hutang jangka panjang dan modal sendiri. Modal sendiri adalah modal yang berasal dari perusahaan itu sendiri (cadangan, laba) atau berasal dari mengambil bagian, peserta, atau pemilik (modal saham, modal peserta dan lain - lain) (Riyanto, 2008). Jadi dapat disimpulkan bahwa debt to equity ratio merupakan perbandingan antara total hutang (hutang lancar dan hutang jangka panjang) dan modal yang menunjukan kemampuan perusahaan untuk memenuhi kewajiban dengan menggunakan modal yang ada. Menurut Syafri (2008) semakin kecil rasio hutang modal maka semakin baik dan untuk keamanan pihak luar rasio terbaik jika jumlah modal lebih besar dari jumlah hutang atau minimal sama.

\section{Current Ratio}

Current ratio merupakan rasio yang menunjukan sejauh dimana aktiva lancar dapat difungsikan untuk menutupi kewajiban jangka pendek atau hutang menjadi lancar. Semakin besar kewajiban yang harus dibayar maka tinggi kemampuan suatu perusahaan dapat menutupi kewajiban jangka pendek semakin tinggi pula.

\section{Opini Audit}

Opini audit merupakan suatu laporan yang diberikan oleh auditor terdaftar yang menyatakan ialah bahwa pemeriksaan sudah dilakukan sesuai dengan norma atau juga aturan pemeriksaan akuntan yang diikuti dengan pendapat tentang kewajaran laporan keuangan yang diperiksa (Tobing \& Nirwana, 2004).

\section{Ukuran Perusahaan}

Ukuran perusahaan adalah skala perusahaan yang dapat dilihat dari total aktiva perusahaan pada akhir tahun. Total penjualan juga dapat digunakan untuk mengukur besarnya perusahaan (Veronica \& Siddharta, 2005). Ukuran perusahaan menggambarkan besar kecilnya perusahaan. Besar kecilnya usaha tersebut ditinjau dari lapangan usaha yang dijalankan. Penentuan skala besar kecilnya perusahaan dapat ditentukan berdasarkan total penjualan, total aset, rata - rata tingkat penjualan (Seftianne \& Handayani, 2011). Perusahaan yang berukuran besar mempunyai berbagai kelebihan dibanding perusahaan berukuran kecil. Kelebihan tersebut yang pertama adalah ukuran perusahaan dapat menentukan tingkat kemudahan perusahaan memperoleh dana dari pasar modal. Kedua, ukuran perusahaan menentukan tawar - menawar dalam kontrak keuangan dan ketiga ada kemungkinan pengaruh skala dalam biaya dan return membuat perusahaan yang lebih besar dapat memperoleh lebih banyak laba (Sawir, 2004).

\section{Keranga Penelitian}

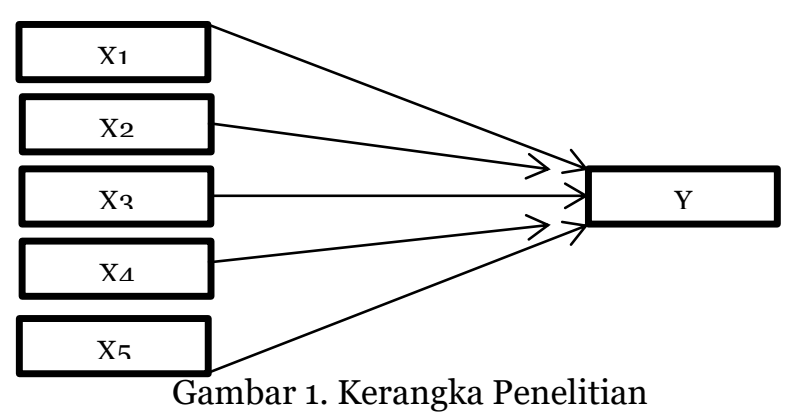

\section{Hipotesis}

H1: Ada pengaruh debt to equity ratio berpengaruh terhadap audit report lag;

H2: Ada pengaruh current ratio berpengaruh terhadap audit report lag;

H3: Ada pengaruh ukuran KAP berpengaruh terhadap audit report lag; 
H4: Ada pengaruh opini audit berpengaruh terhadap audit report lag;

H5: Ada pengaruh ukuran perusahaan berpengaruh terhadap audit report lag

\section{METODE PENELITIAN}

Metode penelitian yang digunakan adalah metode penelitian kuantitatif dengan analisis uji validitas dan reliabilitas, uji normalitas, uji $\mathrm{T}$ dan regresi linear berganda dengan menggunakan software SPSS.

Populasi dalam penelitian ini adalah seluruh perusahaan sub sektor plastik dan kemasan yang terdaftar di Bursa Efek Indonesia periode 2013 - 2018. Sampel dalam penelitian ini sebanyak 11 perusahaan yang memenuhi kriteria penelitian. Sampel dalam penelitian ini menggunakan teknik purposive sampling yaitu teknik pengambilan dengan kriteria tertentu. kriteria yang digunakan pada penelitian ini adalah perusahaan yang mempublikasikan laporan keuangan per 31 Desember yang lengkap secara berturut turut terutama periode 2013 - 2018. Perusahaan sub sektor plastik dan kemasan yang memiliki laba positif periode 2013 2018.

Variabel bebas dalam penelitian ini adalah audit report lag dan variable terikat adalah ratio keuangan, debt equity ratio, current ratio. Ukuran KAP dan opini audit. Jenis data yang digunakan dalam penelitian ini adalah data sekunder berupa laporan keuangan dan laporan tahunan perusahaan sub sektor plastik dan kemasan yang terdaftar di Bursa Efek Indonesia periode 2013 - 2018. Data diperoleh dari situs resmi Bursa Efek Indonesia yaitu www.idx.co.id.

\section{HASIL PENELITIAN PEMBAHASAN}

Berdasarkan uji validitas dan reliabilitas dengan menggunakan SPSS diperoleh $r$ hitung $\geq 0,60$ artinya data valid dan reliabel.

Berdasarkan tabel 1 diperoleh uji normalitas dalam penelitian ini menunjukkan nilai signifikansi sebesar $0,200>0,05$, maka penelitian ini dapat disimpulkan data berdistribusi normal

Tabel 1. Uji Normalitas Kolmogorov Smirnov

\begin{tabular}{ccc}
\hline Variabel & $\begin{array}{c}\text { Kolmogorov } \\
\text { Smirnov }\end{array}$ & Signifikansi \\
\hline Debt Equity & & \\
Ratio & & \\
Current Ratio & & \\
Ukuran KAP & & \\
Opini Audit & 0,200 & \\
Ukuran & & \\
Perusahaan & &
\end{tabular}

Sumber: Data diiolah dengan SPSSa

Berdasarkan table 2 uji model regresi linear berganda diperoleh hasil sebagai berikut:

$\mathrm{Y}=75,719+1,948 \mathrm{X} 1-2,064 \mathrm{X} 2+5,426$

$\mathrm{X}_{3}-13,230 \mathrm{X}_{4}+0,566 \mathrm{X}_{5}$

Tabel 2. Model Regresi Linear Berganda

\begin{tabular}{cc}
\hline Variabel & B \\
\hline (Constant) & 75,719 \\
Debt Equity Ratio & 1,948 \\
Current Ratio & $-2,064$ \\
UkuranKAP & 5,426 \\
Opini Audit & $-13,230$ \\
Ukuran Perusahaan &, 566 \\
\hline
\end{tabular}

Sumber: Data diiolah dengan SPSS

Nilai konstanta adalah 75,719 artinya jika terjadi perubahan variable terikat (nilai varibel bebas adalah o) maka audit report lag adalah 1,927 satuan.

\section{Uji t dan Signifikansi}

Berdasarkan tabel 3 dengan menggunakan SPSS diperoleh data sebagai berikut: tidak ada pengaruh yang signifikan debt equity ratio terhadap audit report lag; ada pengaruh yang signifikan 
current ratio terhadap audit report lag; ada pengaruh yang signifikan ukuran KAP terhadap audit report lag; tidak ada pengaruh yang signifikan opini audit terhadap audit report lag dan tidak ada pengaruh yang signifikan ukuran perusahaan terhadap audit report lag

\begin{tabular}{|c|c|c|c|}
\hline Variabel & $\begin{array}{c}\mathrm{t} \\
\text { Hitung }\end{array}$ & $\mathrm{t}$ tabel & Signifikansi \\
\hline $\begin{array}{l}\text { Debt Equity } \\
\text { Ratio }\end{array}$ & 0,899 & $<1,999$ & 0,372 \\
\hline $\begin{array}{c}\text { Current } \\
\text { Ratio }\end{array}$ & $-2,107$ & $>-1,999$ & 0,039 \\
\hline $\begin{array}{l}\text { Ukuran } \\
\text { KAP }\end{array}$ & 2,038 & $>1,999$ & 0,046 \\
\hline Opini Audit & $-1,319$ & $<-1,999$ & 0,192 \\
\hline $\begin{array}{l}\text { Ukuran } \\
\text { Perusahaan }\end{array}$ & 1,913 & $<1,999$ & 0,061 \\
\hline
\end{tabular}

Sumber: Data diiolah dengan SPSS

\section{Uji F}

Pada tabel 4 hasil uji $\mathrm{F}$ dalam penelitian ini adalah $\mathrm{F}$ hitung $(3,485) \geq \mathrm{F}$ tabel $(2,37)$, maka dapat diartikel bahwa ada pengaruh yang signifikan debt equity ratio, current ratio, ukuran KAP, opini audit dan ukuran perusahaan terhadap audit report lag.

Tabel 4. Hasil Uji Kelayakan Model

\begin{tabular}{cccc}
\hline F & F & Signifikansi & Standard \\
Hitung & Tabel & & \\
\hline 3,485 & $>2,37$ & 0,008 & $<0,05$
\end{tabular}

Sumber: Data diiolah dengan SPSS

\section{Pembahasan}

\section{Debt Equity Ratio terhadap Audit Report Lag}

Hasil pengujian hipotesis 1 menunjukan bahwa debt equity ratio tidak berpengaruh terhadap audit report lag perusahaan industri plastik dan kemasan yang terdaftar di BEI periode 2013 - 2018.
Perusahaan yang memiliki debt-equity ratio yang tinggi ataupun rendah tidak akan mempengaruhi audit report lag sebab setiap perusahaan bertujuan agar kreditor mengetahui kinerja dan kemampuan perusahaan dalam membayar pinjamannya kepada kreditor tersebut. Hal ini dapat disebabkan karena adanya kemungkinan bahwa aturan dan kebijakan mengenai perjanjian utang di Indonesia yang masih relatif tidak ketat untuk mengharuskan penyajian laporan keuangan auditan secara tepat waktu. Artinya, apabila kreditor tidak menentukan secara pasti batas waktu penyajian laporan keuangan auditan suatu emiten maka emiten tidak harus mempercepat proses audit atas laporan keuangannya berapapun besarnya utang yang dimiliki oleh emiten tersebut. Kemungkinan penyebab lainnya adalah perusahaan dapat menyelesaikan permasalahan utang melalui restrukturisasi utang. Selain itu, kondisi utang yang dimiliki suatu perusahaan mungkin dianggap biasa dan bukan menjadi permasalahan yang luar biasa selama masih ada kemungkinan penyelesaiannya (Hariza, et al., 2012).

Hasil penelitian ini sejalan dengan penelitian Hariza et al (2012) yang menyatakana bahwa debt equity ratio tidak berpengaruh terhadap audit report lag.

\section{Current Ratio terhadap Audit Report Lag}

Hasil pengujian hipotesis 2 menunjukkan bahwa current ratio berpengaruh terhadap audit report lag perusahaan industri plastik dan kemasan yang terdaftar di BEI periode 2013-2018. Rasio likuiditas memberi gambaran apakah sebuah perusahaan likuid atau tidak, yaitu apabila kewajiban finansial jangka pendek jatuh tempo, apakah perusahaan mampu 
mengatasi hal tersebut. Likuiditas dalam hal ini current ratio mengacu pada ketersediaan sumber daya perusahaan untuk memenuhi kewjiban jangka pendek yang jatuh tempo secara tepat waktu. Almalia dan Setiady (2006) menyatakan bahwa semakin besar rasio likuiditas, maka hal ini menunjukan kondisi yang baik dari suatu perusahaan. Jika perusahaan mengalami good news, maka perusahaan akan cenderung menyajikan laporan keuangan lebih tepat waktu. Dengan tingkat likuiditas yang tinggi, perusahaan berarti memiliki kemampuan yang tinggi dalam melunasi kewajiban jangka pendeknya. Hal ini merupakan berita baik sehingga perusahaan cenderung untuk tepat wktu dalam penyampaian laporn keuangannya (Fitri dan Nazira, 2009).

Hasil penelitian ini sejalan dengan hasil Fitri dan Nazira (2009) yang menyatakan current ratio berpengaruh terhadap audit report lag.

\section{Ukuran KAP terhadap Audit Report Lag}

Hasil pengujian hipotesis 3 menunjukkan bahwa ukuran KAP berpengaruh terhadap audit report lag perusahaan industri plastik dan kemasan yang terdaftar di BEI periode 2013-2018. Perusahaan industri plastik dan kemasan big four dapat dikatakan bahwa KAP non Four mempunyai tenaga spesialis yang profesional yang mampu melakukan audit secara efisien sehingga mampu menyelesaikan laporan audit dengan tepat waktu sesuai peraturan yang berlaku (Larasari, 2017). Hasil penelitian ini sejalan dengan penelitian Larasati (2017) yang menyatakan bahwa ukuran KAP berpengaruh terhadap audit report lag.

\section{Opini Audit terhadap Audit Report Lag}

Hasil pengujian hipotesis 4 menunjukkan bahwa opini audit tidak berpengaruh terhadap audit report lag perusahaan industri plastik dan kemasan yang terdaftar di BEI periode 2013 2018. Ini dikarenakan auditor yang memiliki pengalaman yang cukup lama tidak menjadi kendala dalam mencari bukti - bukti yang diperlukan dalam proses audit, jadi auditor tidak memerlukan waktu yang lama dalam melakukan proses audit, dari temuan temuan audit yang ada auditor akan mengeluarkan opini audit sesuai dengan bukti temuan tersebut, sehingga laporan audit akan disajikan secara tepat waktu (Larasari, 2017).

Hasil penelitian sejalan dengan Larasari (2017) yang menyatakan bahwa opini audit tidak berpngaruh terhadap audit report lag.

\section{Ukuran Perusahaan terhadap Audit Report Lag}

Hasil pengujian hipotesis 5 menunjukkan bahwa ukuran perusahaan tidak berpengaruh terhadap audit report lag perusahaan industri plastik dan kemasan yang terdaftar di BEI periode 2013 - 2018. Hal ini mengindikasi bahwa ini berarti baik perusahaan berukuran kecil maupun besar dapat saja mengalami keterlambatan dalam penyampaian laporan keuangan. Hal ini dapat diartikan bahwa apabila total aset perusahaan industri plastik dan kemasan yang terdaftar di BEI periode 2013 - 2018 mengalami peningkatan maupun penurunan, maka audit report lag tidak akan mengalami perubahan. Hal ini dikarenakan perusahaan dengan total aset besar maupun kecil mempunyai kemungkinan yang sama 
dalam menghadapi tekanan atas penyampaian laporan keuangan, tekanan tersebut berasal dari pengawasan pihak investor, badan pengawas pasar modal, dan pemerintah. Oleh karena itu, Auditor akan memeriksa perusahaan dengan total aset besar maupun kecil dengan cara yang sama sesuai dengan prosedur dalam standar professional akuntan publik.

Temuan penelitian sejalan dengan yang dilakukan oleh Haryanto (2014), Saemargani dan Mustikawati (2015), juga memberikan bukti empiris bahwa ukuran perusahaan yang diproksikan dengn logaritma natural total aset tidak mempiliki pengaruh terhadap audit report lag perusahaan.

\section{KESIMPULAN}

Debt equity ratio tidak berpengaruh terhadap audit report lag. Perusahaan yang memiliki debt-equity ratio yang tinggi ataupun rendah tidak akan mempengaruhi audit report lag sebab setiap perusahaan bertujuan agar kreditor mengetahui kinerja dan kemampuan perusahaan dalam membayar pinjamannya kepada kreditor tersebut.

Current ratio berpengaruh terhadap audit report lag. Likuiditas dalam hal ini current ratio mengacu pada ketersediaan sumber daya perusahaan untuk memenuhi kewjiban jangka pendek yang jatuh tempo secara tepat waktu.

Ukuran KAP berpengaruh terhadap audit report lag. Perusahaan industri plastik dan kemasan big four dapat dikatakan bahwa KAP non Four mempunyai tenaga spesialis yang profesional yang mampu melakukan audit secara efisien sehingga mampu menyelesaikan laporan audit dengan tepat waktu sesuai peraturan yang berlaku.

Opini audit tidak berpengaruh terhadap audit report lag. Ini dikarenakan auditor yang memiliki pengalaman yang cukup lama tidak menjadi kendala dalam mencari bukti - bukti yang diperlukan dalam proses audit, jadi auditor tidak memerlukan waktu yang lama dalam melakukan proses audit, dari temuan temuan audit yang ada auditor akan mengeluarkan opini audit sesuai dengan bukti temuan tersebut, sehingga laporan audit akan disajikan secara tepat waktu.

Ukuran perusahaan tidak berpengaruh terhadap audit report lag. Apabila total aset perusahaan industri plastik dan kemasan yang terdaftar di BEI periode 2013 - 2018 mengalami peningkatan maupun penurunan, maka audit report lag tidak akan mengalami perubahan.

\section{Daftar Pustaka}

Almalia L. S., dan Setiadi L, (2006). FaktorFaktor Yang Mempengaruhi Penyelesai Penyajian Laporan Keuangan Pada Perusahaan Yang Terdaftar di BEJ. Seminar Nasional Good Corporate Governance

Arens dan Loebbecke, (2003). Auditing Pendekatan Terpadu. Edisi Indonesia. Jakarta: Salemba Empat

Fimanti, F (2016). Faktor-Faktor Yang Mempengaruhi Audit Report Lag. Jurnal Bisnis dan Akuntansi Volume 18 No 2, halaman $167-175$

Fitri, F. A. Dan Nazira, (2009). Analisis Ketepatan Waktu Penyampaian Laporan Keuangan Kepada Publik: Studi Empiris Pada Perusahaan Manufaktur Yang Terdaftar di BEI. 
Jurnal Telah dan Riset Akuntansi Volume 2 No 2, halaman $198-214$

Ghozali, I., (2012). Aplikasi Analisis Multivariate Dengan Program IBM SPSS. Yogyakarta: Universitas Diponegoro.

Hariza, Et Al., (2012). Faktor-Faktor Yang Mempengaruhi Audit Report Lag (Studi Empiris Pada Emiten Industri Keuangan di BEI). Jurnal Akuntansi Universitas Jember, halaman 30 - 48 Haryanto, A. M., (2014). Analisis FaktorFaktor Yang Mempengaruhi Audit Delay. Jurnal Akuntansi dan Keuangan Volumen 3 No 2

Indriani, R. E., dan Supriyani, (2012). Faktor-Faktor Yang Mempengaruhi Audit Report lag Pada Perusahaan manufaktur Yang Terdaftar di Indonesia dan Malaysia. The Indonesia Accounting Review, Volume 2 No 2, Halaman 185 - 202.

Iskandar, M. J., dan Trsinawati, E. (2020). Faktor-Faktor Yang Mempengaruhi Audit Report lag Pada Perusahaan manufaktur Yang Terdaftar di Bursa Efek Indonesia. Jurnal Bisnis dan Akuntansi, Volume 12 No 3, Halaman 175 -186.

Pramaharjan, B., (2015). Faktor-Faktor Yang Berpengaruh terhadap Audit Report Lag Pada Perusahaan Manufaktur. Jurnal Akuntansi dan Binsis Universitas Diponegoro

Riyanto, B., (2008). Dasar-dasar pembelajaran Perusahaan. Yogyakarta: BPFE

Saemargani, F. I. Dan Mustikawati, I., (2015). Pengaruh Ukuran perusahaan, Umur Perusahaan, Profitabilitas, Solvabilitas, Ukuran KAP dan Opini Auditor Terhadap Audit Delay. Jurnal Nominal Bol 4 No 2

Sawir, A., (2004). Analisis Kinerja Keuangan dan Perencanaan
Keuangan Perusahaan. Jakarta: PT Gramedia Pustaka Utama

Seftianne dan Handayani, R., (2011). Faktor-Faktor Yang Mempengaruhi Struktur Modal Pada Perusahaan Publik sektor Manufaktur. Jurnal Bisnis dan Akuntansi Vol 13 No 1, halaman $39-56$

Syafri, S. H., (2008). Analisis Krisis atas Laporan Keuangan. Jakarta: PT Raja Grafindo Persada 